\title{
Impact of the First Wave of COVID-19 on Physical Activity Promotion in the European Union: Results From a Policymaker Survey
}

\author{
Peter Gelius, Antonina Tcymbal, Stephen Whiting, Sven Messing, Karim Abu-Omar, Wolfgang Geidl, \\ Anne Kerstin Reimers, Klaus Pfeifer, Romeu Mendes, Nino Berdzuli, and Joao Breda
}

\begin{abstract}
Background: The COVID-19 pandemic is a major challenge for societies and governments around the world that severely affects all aspects of health promotion. This study assesses the potential influence of the first wave of the pandemic on national physical activity promotion policy in the European Union (EU). Methods: Data were collected using an online survey among members of the EU Physical Activity Focal Point Network, which consists of government officials from all EU member states. Results: The COVID-19 pandemic has significantly affected physical activity promotion across the EU. In particular, experts indicated that it has negatively impacted opportunities for physical activity in their countries. There have, however, been positive effects of the crisis on public awareness of physical activity. While almost all countries were able to issue physical activity recommendations during quarantine, opinions varied regarding the overall impact of the pandemic on governmental capacities for physical activity promotion and policy. Conclusions: This study shows that the COVID-19 crisis has had both negative and positive effects on physical activity promotion in the EU. The positive experiences reported by some members of the Focal Point Network may assist other countries in identifying potential policy windows and strategies for the ongoing pandemic.
\end{abstract}

Keywords: health policy, physical activity policy, physical activity recommendations

COVID-19, which was declared to be a global pandemic by the World Health Organization (WHO) on March 11, 2020, ${ }^{1}$ has severely affected the WHO European Region. By the end of October 2020 , the total number of confirmed cases in the region had exceeded 10 million. ${ }^{2}$ As Europe is currently entering the entering the third or even fourth waves of the pandemic, it is evident that while European Union (EU) member states have all suffered from COVID-19, infection and death rates have varied substantially between nations.

Following the first wave of outbreaks in the spring of 2020, most countries began implementing regional and national crisis management plans to contain the virus and support the response of national healthcare systems. Since the virus spreads via human-to-human transmission, ${ }^{3}$ social and physical distancing were key elements of most regional action plans to prevent its spread. In many countries, this involved requesting citizens to self-quarantine for prolonged periods of time, severely impacting everyday life. COVID-19 containment measures also had an enormous impact on sports and exercise participation, as both individual physical activity (PA) and team sports were suspended; public sports facilities, gyms, parks, playgrounds, and sports clubs were forced to close. ${ }^{4}$ Furthermore, the temporary shutdown of workplaces, schools, and institutions of higher education caused many individuals to miss out on PA in their daily routines, such as active travel (walking and cycling). Recent studies have assessed changes in PA levels during the first wave of the pandemic and have shown that people with a lower income, ${ }^{5}$ lower educational

Gelius, Tcymbal, Messing, Abu-Omar, Geidl, Reimers, and Pfeifer are with the Department of Sport Science and Sport, Friedrich-Alexander-Universität ErlangenNürnberg, Erlangen, Germany. Whiting and Mendes are with the EPIUnit, Instituto de Saúde Pública, Universidade do Porto, Porto, Portugal. Whiting, Mendes, and Breda are with the European Office for the Prevention and Control of Noncommunicable Diseases, WHO Office for Europe, Moscow, Russian Federation. Berdzuli is with the the Division of Country Health Programmes, WHO Regional Office for Europe, Copenhagen, Denmark. Gelius (peter.gelius@fau.de) is corresponding author. attainment, ${ }^{6}$ and lower levels of PA before the pandemic ${ }^{6,7}$ were particularly negatively affected by these lockdown measures.

While the impact of COVID-19 containment efforts on PA behavior is rather well documented at present, ${ }^{8}$ their influence on PA promotion policy and noncommunicable disease (NCD) prevention efforts remains unclear. Over the last decade, policies to increase PA prevalence rates ${ }^{9}$ have evolved rapidly, resulting in the development of relevant documents by international organizations such as WHO, ${ }^{10}$ the WHO Regional Office for Europe, ${ }^{11}$ and the EU. ${ }^{12}$ These policies have acted as an important catalyst in stimulating national-level PA promotion policy development ${ }^{13}$ and formulating national PA recommendations. ${ }^{14}$

As part of the policy response to counteract the problem of declining PA levels during the COVID-19 pandemic, WHO initiated the campaign \#HealthyAtHome and published specific PA recommendations for people in self-quarantine. ${ }^{15,16}$ These efforts were supported by additional recommendations for PA and exercise during the pandemic published by international academics. ${ }^{17,18}$

However, given the extreme pressure placed on national public health systems by COVID-19, it is uncertain to what extent countries have been able to mirror these initiatives at the national level, as both funding and institutional capacities may be redirected towards other areas related to mitigating the impact of the pandemic. Based on a policymaker survey among members of the EU PA Focal Point Network, this study aimed to identify the impact of the first wave of COVID-19 on national efforts for PA promotion in the EU. The results provide valuable insights regarding national PA policy capacities in response to the first wave of COVID-19, and may hold important clues for PA policy development and decision making as the pandemic progresses.

\section{Methods}

The EU PA Focal Point Network was founded in 2014 and currently includes all $27 \mathrm{EU}$ Member States. Its purpose is to 
monitor the implementation of the 2013 EU Council Recommendation on Health-Enhancing PA across Sectors ${ }^{12}$ and to support exchange on PA promotion policy between countries. The network is run by the European Commission's Directorate-General for Education and Culture with support from the WHO Regional Office for Europe. Member states nominate representatives to the network, usually from the sport (eg, ministry of sport or national sport agency) or health sector (eg, ministry of health or national public health institute). Some nations are represented by more than one expert, for example, from different regions or sectors.

For the study at hand, the WHO European Office for Europe, together with the WHO Collaborating Centre for PA and Public Health at the Friedrich-Alexander University (Erlangen, Germany), developed an online questionnaire to measure the impact of the COVID-19 crisis on PA levels, PA policy, and PA promotion in the member states, as well as the day-to-day work of the focal points themselves. An invitation was sent via e-mail to all focal points by the WHO Regional Office for Europe on May 15, 2020, asking them to complete the survey by June 22 .

\section{Results}

In total, $29 \mathrm{EU}$ focal point experts from $24 \mathrm{EU}$ member states filled out the questionnaire. Austria, Bulgaria, Croatia, Estonia, Finland, France, Greece, Hungary, Latvia, Lithuania, Luxembourg, Malta, Netherlands, Poland, Portugal, Romania, Slovakia, Slovenia, Spain, and Sweden were represented by one expert; Cyprus, Denmark, and Italy by 2 experts; and Belgium by 3 experts. All experts noted the negative impact of quarantine regulations on opportunities for PA in their countries, with 2 experts rating this impact as minimal and eleven as severe (Table 1 and Figure 1). In almost all countries, indoor sports facilities were closed by the government; some also prohibited the use of outdoor playgrounds, parks, and recreational areas. In some cases, outdoor PA was limited to 1 hour per day in the immediate vicinity of one's home or even completely forbidden for a certain period during lockdown.

Experts from 22 countries reported that $P A$ recommendations or other information on how to maintain adequate PA levels during quarantine were issued by their countries; one expert stated that recommendations were currently underway. These recommendations encouraged individuals to stay active and provided instructions (often illustrated) on possible exercises and on how to organize one's PA during lockdown. Advice was generally related to PA at home. According to the respondents, the production and dissemination of the recommendations were often achieved through joint efforts by public, private, and nonprofit organizations. This included the production of instructional videos, the organization of social media and TV campaigns, and the provision of free online classes to promote PA during the COVID-19 crisis.

Almost half of the experts (45\%) stated that COVID-19 had a negative impact on general NCD and PA policy in their countries. Some of the explanations provided included the serious financial problems in the sports sector caused by the crisis and severe obstacles to the implementation of national PA programs, for example, the inability to hold in-person meetings. By contrast, $21 \%$ of the focal points declared that the crisis had a somewhat positive impact on general NCD/PA policy. Two of them mentioned that political authorities supported and promoted PA. One expert stated that the pandemic prompted the use of new innovative tools and actions to promote PA, and another indicated that COVID-19 had helped them find new partners among institutions with whom they had not previously cooperated.
Most of the experts (75.5\%) reported that the pandemic has had a positive impact on public awareness of PA. They indicated that individuals were more motivated to take advantage of different opportunities to be physically active after observing negative effects of their own decreasing PA levels. In addition, they saw PA as a good opportunity to be outside without breaking lockdown rules. COVID19 also prompted health promotion organizations to use new tools, such as social media, web platforms, TV shows, and free online courses for PA promotion. In addition, both the media and government authorities presented the health benefits of PA more precisely than before. Disagreeing with the majority, 4 experts (14\%) reported that public awareness for PA was negatively affected by the crisis, albeit without providing any detailed explanations.

Respondents' assessments of the impact of the crisis on their own work as PA officers and focal points were very diverse, ranging from severely negative to very positive. Half the experts (51\%) rated the impact as negative, as activities and programs under their purview were reduced or postponed and more actions directly related to containing COVID-19 were given top priority. Meanwhile, 5 experts (18\%) experienced positive effects of the crisis on their work, for example, because it allowed them to use new online tools, find new partners, and cooperate more closely with other sectors.

\section{Discussion}

The current study has attempted to shed some light on the potential influence of the first wave of the COVID-19 pandemic on PA promotion policy efforts in EUmember states. While the results are based on survey data collected in 2020, their relevance is heightened by the onset of the onset of further waves of the COVID-19 pandemic and associated "partial lockdowns" in many European countries. Both the challenges and opportunities experienced by focal points earlier this year hold important clues for PA policy during the current crisis or in future pandemics, and can ensure that PA promotion does not get dropped from national policy agendas in light of other, more "pressing" issues.

Two positive trends shown in the results are that respondents reported increased public awareness of PA during the pandemic, and that 22 countries were able to prepare and disseminate specific recommendations on PA during quarantine. This is particularly noteworthy as all focal points initially suspected that COVID-19 had a negative impact on PA opportunities in EU member states.

By contrast, assessments of COVID-19's impact on PA policy were divided between policymakers reporting a potentially positive influence and those stressing the negative consequences. From a theoretical perspective, it might be particularly useful to draw upon theories of the policy process ${ }^{19}$ to explain this divergence in expert opinion. One line of thinking would variously conceptualize counteracting physical inactivity as a "wicked,"20 "chronic," 21 or even "super wicked" 22 policy problem characterized by competing views about both its causes (lack of individual discipline or structural inequality of opportunities) and appropriate solutions (health education or infrastructure improvements ${ }^{20}$ ). This would be further complicated by the need to engage multiple policy sectors $^{21,23}$ and long timelines to achieve actual public health benefits.

From this perspective, the ongoing pandemic is likely to make it even more difficult to develop policies to promote PA in the short term: COVID-19 containment could be seen not only as more urgent, but also as a more straightforward public health policy problem, with a broader political consensus (eg, about the use of face-masks to slow the spread of the virus), clearer 


\begin{tabular}{|c|c|c|c|c|}
\hline $\begin{array}{l}\text { Expert } \\
\text { No. }\end{array}$ & $\begin{array}{l}\text { Impact on PA } \\
\text { opportunities in country }\end{array}$ & Impact on NCD/PA policy & $\begin{array}{l}\text { Effect on public awareness for } \\
\text { PA }\end{array}$ & Impact on work as a FP \\
\hline 1 & Some negative impact & Some negative impact & Some positive effects & No impact/so-so \\
\hline 2 & Some negative impact & Do not know & Some positive effects & Some positive impact \\
\hline 3 & Severe negative impact & Severe negative impact & Extremely positive effects & No impact/so-so \\
\hline 4 & Severe negative impact & Some positive impact & Some positive effects & Do not know \\
\hline 5 & Severe negative impact & Do not know & Extremely positive effects & No impact/so-so \\
\hline 6 & Severe negative impact & Some negative impact & Do not know & Some negative impact \\
\hline 7 & Some negative impact & No impact/so-so & Some positive effects & Severe negative impact \\
\hline 8 & Some negative impact & No impact/so-so & Some positive effects & Severe negative impact \\
\hline 9 & Some negative impact & Some negative impact & Extremely positive effects & Some positive impact \\
\hline 10 & Severe negative impact & Severe negative impact & Extremely negative effects & No impact/so-so \\
\hline 11 & Severe negative impact & Do not know & Extremely positive effects & No impact/so-so \\
\hline 12 & Some negative impact & Severe negative impact & Some positive effects & Some negative impact \\
\hline 13 & Some negative impact & Some positive impact & Some positive effects & Some positive impact \\
\hline 14 & Minimal negative impact & Some positive impact & Some positive effects & Some negative impact \\
\hline 15 & Some negative impact & Some positive impact & Some positive effects & Some negative impact \\
\hline 16 & Some negative impact & Some negative impact & Some negative effects & Severe negative impact \\
\hline 17 & ievere negative impact & Severe negative impact & Extremely negative effects & No answer \\
\hline 18 & Some negative impact & Some positive impact & Some negative effects & No impact/so-so \\
\hline 19 & Some negative impact & Some negative impact & Extremely positive effects & Severe negative impact \\
\hline 20 & Some negative impact & Do not know & No effect/so-so & No impact/so-so \\
\hline 21 & jevere negative impact & Some positive impact & Some positive effects & Very positive impact \\
\hline 22 & Some negative impact & No impact/so-so & Some positive effects & Some positive impact \\
\hline 23 & Some negative impact & No impact/so-so & Some positive effects & Some negative impact \\
\hline 24 & Severe negative impact & Some negative impact & Some positive effects & Very positive impact \\
\hline 25 & Some negative impact & Do not know & Some positive effects & Some negative impact \\
\hline 26 & Severe negative impact & Some negative impact & Some positive effects & Some negative impact \\
\hline 27 & Some negative impact & Some negative impact & Some positive effects & Some negative impact \\
\hline 28 & Severe negative impact & Some negative impact & Some positive effects & Severe negative impact \\
\hline 29 & Minimal negative impact & No impact/so-so & No effect/so-so & Some negative impact \\
\hline
\end{tabular}

Figure 1 - Overview of responses to the survey on impact of the COVID-19 pandemic on PA opportunities, recommendations, policy, public awareness, and the work of national PA FPs by individual experts. FP indicates focal point; NCD, noncommunicable disease; PA, physical activity. 
Table 1 Results of the Survey on Impact of the COVID19 Pandemic on PA Opportunities, Recommendations, Policy, Public Awareness, and the Work of National PA Focal Points

\begin{tabular}{|c|c|c|}
\hline & Number & Percentage \\
\hline \multicolumn{3}{|c|}{$\begin{array}{l}\text { Overall, to what extent do current quarantine } \\
\text { regulations in your country restrict } \\
\text { opportunities for PA? ( } n=29 \text { experts) }\end{array}$} \\
\hline Severe negative impact & 11 & 38 \\
\hline Some negative impact & 16 & 55 \\
\hline Minimal negative impact & 2 & 7 \\
\hline No negative impact at all & 0 & 0 \\
\hline \multicolumn{3}{|l|}{$\begin{array}{l}\text { Has your country issued any } \\
\text { recommendations or other materials for the } \\
\text { population on how to maintain adequate PA } \\
\text { levels during quarantine? ( } n=24 \text { countries) }\end{array}$} \\
\hline Yes & 22 & 92 \\
\hline In preparation & 1 & 4 \\
\hline Discrepancy in the experts' responses & 1 & 4 \\
\hline \multicolumn{3}{|l|}{$\begin{array}{l}\text { How would you assess the impact of the } \\
\text { COVID- } 19 \text { crisis on general NCD/PA policy } \\
\text { in your country? ( } n=29 \text { experts) }\end{array}$} \\
\hline Severe negative impact & 3 & 11 \\
\hline Some negative impact & 10 & 34 \\
\hline No impact/so-so & 5 & 17 \\
\hline Some positive impact & 6 & 21 \\
\hline Very positive impact & 0 & 0 \\
\hline Do not know & 5 & 17 \\
\hline \multicolumn{3}{|l|}{$\begin{array}{l}\text { As far as you can tell, has public awareness } \\
\text { (eg, in the media and on social platforms) of } \\
\text { PA been affected by the COVID-19 crisis? } \\
\text { ( } \mathrm{n}=29 \text { experts) }\end{array}$} \\
\hline Extremely positive effects & 5 & 17 \\
\hline Some positive effects & 17 & 58.5 \\
\hline No effect/so-so & 2 & 7 \\
\hline Some negative effects & 2 & 7 \\
\hline Extremely negative effects & 2 & 7 \\
\hline Do not know & 1 & $3 \cdot 5$ \\
\hline \multicolumn{3}{|l|}{$\begin{array}{l}\text { How would you assess the impact of the } \\
\text { COVID- } 19 \text { crisis on your work as a PA } \\
\text { officer and focal point? ( } n=29 \text { experts) }\end{array}$} \\
\hline Severe negative impact & 5 & 17 \\
\hline Some negative impact & 10 & 34 \\
\hline No impact/so-so & 7 & 24 \\
\hline Some positive impact & 3 & 11 \\
\hline Very positive impact & 2 & 7 \\
\hline Do not know & 1 & 3.5 \\
\hline N/A & 1 & 3.5 \\
\hline
\end{tabular}

Abbreviations: NCD, noncommunicable disease; PA, physical activity.

leadership (by the health sector), and quicker benefits for policymakers (a clear drop in infections after the mandatory introduction of face-masks ${ }^{24}$ ). With many national budgets depleted by the current crisis, it seems only logical that NCD prevention will be put on the back burner until the pandemic has been successfully contained.
The other, and more optimistic, perspective is based on the Multiple Streams Approach, ${ }^{25-27}$ which assumes that political change occurs in the rare occasion when 3 distinct streams of policy process come together: a particular issue is perceived by the public as important (problem stream), solutions are developed (policy stream), and there is political consensus that the problem should be dealt with (politics stream). Such a constellation forms a window of opportunity which allows certain actors (termed "policy entrepreneurs") to initiate policy change..$^{27}$ From this perspective, COVID-19 may indeed have opened a policy window for the development of PA promotion and NCD prevention policies.

For example, the risk of COVID-19 infections in public transport (problem stream) triggered some nations to develop policies that support walking or cycling (policy stream), for example, in the form of "pop-up bike lanes." 28 Policy entrepreneurs in these nations have presumably been able to advance such policies at the local level and to convince relevant political decision makers (politics stream) to support them. Other NCD prevention policies may also benefit from this window of opportunity, for example, policies to combat and prevent obesity based on recent evidence that overweight individuals tend to be more severely affected by COVID-19 than those with a healthy body weight. ${ }^{29}$ Recent developments, however, also suggest that these PA-friendly policies may again be under renewed pressure as the pandemic drags on, for example, where temporary bike lanes have been dismantled as a result of pressure from the automobile lobby or in anticipation of increased motorized traffic during the upcoming winter months..$^{30}$

The authors' results suggest that both scenarios-the optimistic and pessimistic - have been observed by policymakers and health promotors in EU member states since the beginning of the pandemic. It may be particularly worthwhile for countries that have been negatively impacted to explore whether the upcoming months pose a window of opportunity for PA and NCD policies. The positive experiences reported by some of the focal points might guide others to identify potential policy windows and policy entrepreneurs in their countries. The EU PA Focal Point Network might provide a suitable platform for such an exchange by helping experts share best practices in PA policies, support each other in the development of national PA recommendations, or receive scientific input. Similar networks could potentially also help advance national policymaking during and after the COVID-19 pandemic in other WHO Regions.

\section{Acknowledgments}

The writing group takes sole responsibility for the content of this article and the content of this article reflects the views of the authors only. N.B., J.B., R.M., and S.W. are staff members of the WHO. The authors alone are responsible for the views expressed in this publication and they do not necessarily represent the decisions or the stated policy of the WHO. Data are available upon written request from the WHO Regional Office for Europe, but written consent of the PA Focal Points of involved countries, the European Commission, and the WHO Regional Office for Europe may be required. The authors declare that they have no competing interests. This research received no specific grant.

\section{References}

1. World Health Organization. WHO Director-General's opening remarks at the media briefing on COVID-19-11 March 2020. 2020. https://www. who.int/dg/speeches/detail/who-director-general-s-opening-remarks-atthe-media-briefing-on-covid-19---11-march-2020. 
2. World Health Organization. COVID-19: latest updates. 2020. https:// us4.campaign-archive.com/?u=bb832ff4c9f8efad547ffcf69\&id=3b2 5cd4922. Accessed November, 3, 2020.

3. Li Q, Guan X, Wu P, et al. Early transmission dynamics in Wuhan, China, of novel coronavirus-infected pneumonia. $N$ Engl J Med. 2020;382(13):1199-1207. doi:10.1056/NEJMoa2001316

4. United Nations. The impact of COVID-19 on sport, physical activity and well-being and its effects on social development. 2020. https:// www.un.org/development/desa/dspd/wp-content/uploads/sites/22/ 2020/05/PB_73.pdf.

5. Smith L, Jacob L, Butler L, et al. Prevalence and correlates of physical activity in a sample of UK adults observing social distancing during the COVID-19 pandemic. BMJ Open Sport Exerc Med. 2020;6(1): e000850. doi:10.1136/bmjsem-2020-000850

6. Constandt B, Thibaut E, De Bosscher V, Scheerder J, Ricour M, Willem A. Exercising in times of lockdown: an analysis of the impact of COVID-19 on levels and patterns of exercise among adults in Belgium. Int J Environ Res Public Health. 2020;17(11):4144. PubMed ID: 32532013 doi:10.3390/ijerph17114144

7. Lesser IA, Nienhuis CP. The impact of COVID-19 on physical activity behavior and well-being of Canadians. Int J Environ Res Public Health. 2020;17(11):3899. PubMed ID: 32486380 doi:10. 3390/ijerph17113899

8. Tison GH, Avram R, Kuhar P, et al. Worldwide effect of COVID-19 on physical activity: a descriptive study. Ann Intern Med. 2020; 173(9):767-770. PubMed ID: 32598162 doi:10.7326/M20-2665

9. Breda J, Jakovljevic J, Rathmes G, et al. Promoting healthenhancing physical activity in Europe: current state of surveillance, policy development and implementation. Health Policy. 2018; 122(5):519-527. PubMed ID: 29422372 doi:10.1016/j.healthpol. 2018.01.015

10. World Health Organization. Global Action Plan on Physical Activity 2018-2030: More Active People for a Healthier World. 2018. Geneva, Switzerland: World Health Organization.

11. World Health Organization. Physical Activity Strategy for the WHO European Region 2016-2025. 2016, Copenhagen, Denmark: World Health Organization.

12. European Commission. Commission Staff Working Document: A Monitoring Framework for the Implementation of Policies to Promote Health-Enhancing Physical Activity (HEPA), Based on the EU Physical Activity Guidelines (SWD(2013) 310 final). 2013. Brussels, Belgium: European Commission.

13. Bull F, Milton K, Kahlmeier S, et al. Turning the tide: national policy approaches to increasing physical activity in seven European countries. Br J Sports Med. 2015;49(11):749-756. PubMed ID: 24682248 doi:10.1136/bjsports-2013-093200

14. Gelius P, Tcymbal A, Abu-Omar K, et al. Status and contents of physical activity recommendations in European Union countries: a systematic comparative analysis. BMJ Open. 2020;10(2): e034045. PubMed ID: 32086356 doi:10.1136/bmjopen-2019034045
15. World Health Organization. \#HealthyAtHome-physical activity. 2020. https://www.who.int/news-room/campaigns/connectingthe-world-to-combat-coronavirus/healthyathome/healthyathome--physical-activity.

16. World Health Organization. Stay physically active during selfquarantine. 2020. https://www.euro.who.int/en/health-topics/healthemergencies/coronavirus-covid-19/technical-guidance/stay-physicallyactive-during-self-quarantine.

17. Bloch W, Halle M, Steinacker JM. Sport in times of corona. German J Sport Med. 2020;71:83-84.

18. Sallis JF, Pratt M. Multiple benefits of physical activity during the coronavirus pandemic. Rev Bras Ativ Fís Saúde. 2020;25:1-5. doi: $10.12820 /$ rbafs. $25 \mathrm{e} 0112$

19. Sabatier PA. Theories of the Policy Process, 2nd ed. New York, NY: Avalon Publishing; 2007.

20. Rittel HWJ, Webber MM. Dilemmas in a general theory of planning. Policy Sciences. 1973;4(2):155-169. doi:10.1007/BF01405730

21. Peters GB. The problem of policy problems. J Comp Policy Anal. 2005;7(4):349-370.

22. Levin K, Cashore B, Bernstein S, Auld G. Overcoming the tragedy of super wicked problems: constraining our future selves to ameliorate global climate change. Policy Sci. 2012;45(2):123-152. doi:10.1007/ s11077-012-9151-0

23. Rütten A, Abu-Omar K, Gelius P, Schow D. Physical inactivity as a policy problem: applying a concept from policy analysis to a public health issue. Health Res Policy Syst. 2013;11(1):9. PubMed ID: 23496998 doi:10.1186/1478-4505-11-9

24. Worby CJ, Chang H-H. Face mask use in the general population and optimal resource allocation during the COVID-19 pandemic. Nat Commun. 2020;11(1):4049. PubMed ID: 32792562 doi:10.1038/ s41467-020-17922-x

25. Jones MD, Peterson HL, Pierce JJ, et al. A river runs through it: a multiple streams meta-review. Policy Stud J. 2016;44(1):13-36. doi: $10.1111 /$ psj. 12115

26. Zahariadis N. Ambiguity, time, and multiple streams. In: Sabatier P, ed. Theories of the Policy Process. Coulder, CO: Westview Press; 1999.

27. Kingdon JW. Agendas, Alternatives, and Public Policies. Boston, MA: Little, Brown; 1984.

28. Union Cycliste Internationale. Pop-up bike lanes: a rapidly growing transport solution prompted by coronavirus pandemic. 2020. https://www.uci.org/news/2020/pop-up-bike-lanes-a-rapidly-growingtransport-solution-prompted-by-coronavirus-pandemic. Accessed July, 31, 2020.

29. Docherty AB, Harrison EM, Green CA, et al. Features of 16,749 hospitalised UK patients with COVID-19 using the ISARIC WHO clinical characterisation protocol. medRxiv. 2020. doi:10.1101/2020. 04.23.20076042

30. Dambeck H, Stotz P. Deutschland verpasst die Verkehrswende. 2020. https://www.spiegel.de/auto/paris-und-barcelona-schlagen-berlindatenanalyse-von-sechs-verkehrswende-projekten-a-031c2766-f5994794-996f-ce947c370d20. Accessed November, 2, 2020. 